\title{
The Latest Generation of SEZs: Consumer-Oriented Unilateralism in China's E-commerce Trade
}

\author{
Jie (Jeanne) Huang*
}

\begin{abstract}
WTO multilateralism is driven by manufacturers. However, in China, Cross-border E-commerce Retail Import ('CERI') has spurred a new, consumer-oriented trade unilateralism. CERI prospers within China's National Cross-Border E-commerce Pilot Cities, which are Special Economic Zones aimed at using unilateral trade liberalization to meet consumers' growing demands for high-quality foreign products. CERI enhances consumer benefits beyond reducing customer formalities and tax rates and lowering product prices. It re-conceptualizes consumer protection by treating consumers as diverse individuals rather than as a homothetic group. It also empowers consumers by making them 'importers' to minimize behind-the-border trade barriers. CERI warrants a rethinking of WTO multilateralism from its initial focus on corporations and capital owners to a revised focus on consumers.
\end{abstract}

Key words: cross-border e-commerce retail import, China, consumer, trade unilateralism, Special Economic Zones

International trade rules negotiated through the World Trade Organization ('WTO') aim to liberalize trade in goods by reducing tariff and non-tariff barriers as well as restricting behindthe-border discriminatory measures against foreign products and suppliers. ${ }^{1}$ WTO

\footnotetext{
* Jie (Jeanne) Huang, Associate Professor, University of Sydney Law School. The paper was presented at a panel discussion organised by the Sydney Law School and the Sydney China Studies Centre in 2020 titled 'From Tariff to Technology: Upgrading the China-Australia FTA in the post-Pandemic Era'. The author is very grateful for comments received from that seminar and from Professors Julien Chaisse and Georgios Dimitropoulos and the two anonymous reviewers. The research leading to this paper is supported by the University of Sydney-Shanghai Jiaotong University Partnership Award (2019) and the China Social Science Fund (16BFX202). All errors remain that of the author, and all comments are welcome at Jeanne.huang@sydney.edu.au.

${ }^{1}$ Robert Baldwin, 'The Case for a Multilateral Trade Organization', in Martin Daunton, Amrita Narlikar, and Robert M. Stern (eds), The Oxford Handbook on The World Trade Organization (Oxford: Oxford University Press, 2012) 1. 'Products' refers to tangible products or digital/intangible products with tangible carriers.
} 
multilateralism (sometimes complemented by Free Trade Agreements ('FTAs')) has reduced, though not yet eliminated, the separation between domestic and foreign markets. ${ }^{2}$ Although international trade is ultimately aimed at consumers, ${ }^{3}$ WTO multilateralism is directly driven by manufacturers. ${ }^{4}$ The WTO aims to facilitate access to, and ensure non-discriminatory treatment in, foreign markets for products, services and their providers, and intellectual property rights and rights holders. ${ }^{5}$ Although WTO multilateralism can ultimately reduce the risk of product and service shortages and improve consumer welfare, the WTO has limited regulations on consumer protection. ${ }^{6}$ This is largely because most consumers are never directly involved in international trade as they buy foreign products in domestic rather than foreign markets.

In China, Cross-border E-commerce Retail Import ('CERI') refers to a trade model where Chinese consumers purchase products overseas on cross-border e-commerce platforms and import them to China through Bonded Import or Direct Import. ${ }^{7}$ CERI enables consumers to import foreign products to China without travelling across the border and eliminates the need for an importing middleman. ${ }^{8}$ CERI occurs within China's National Cross-Border E-commerce Pilot Cities ('Pilot Cities'), which are Special Economic Zones ('SEZ') aimed at promoting imports for consumption. ${ }^{9}$ Amidst the US-China trade war, China has shown determination to use CERI to achieve further trade liberalization by doubling the number of CERI Pilot Cities

\footnotetext{
${ }^{2}$ See generally Robert Howse, 'Making the WTO (Not So) Great Again: The Case Against Responding to the Trump Trade Agenda Through Reform of WTO Rules on Subsidies and State Enterprises', 23 Journal of International Economic Law 371 (2020), at 371-389.

${ }^{3}$ In this Article, 'consumers' are defined as natural persons who buy products solely for personal use. They can send products as gifts but cannot resell them for profit. 'Chinese consumers' refers to Chinese nationals because only Chinese nationals are eligible to enjoy the tariff exemption and tax reduction discussed in Section III.A.1 below.

${ }^{4}$ Rolland Sonia, 'Are Consumer-Oriented Rules the New Frontier of Trade Liberalization', 55 Harvard International Law Journal 361 (2014), at 388; Debra P Steger, 'The Future of the WTO: The Case for Institutional Reform', 12 Journal of International Economic Law 803 (2009), at 833.

${ }^{5}$ John H Jackson, Sovereignty, the WTO, and Changing Fundamentals of International Law (Cambridge: Cambridge University Press, 2006) 84.

${ }^{6}$ Jie Huang, 'Comparison of E-commerce Regulations in Chinese and American FTAs-Converging Approaches, Diverging Contents, and Polycentric Directions', 64 Netherlands International Law Review 309 (2017), at 313.

${ }^{7}$ Article 1 of the Circular on Improving the Oversight of CERI issued by the Ministry of Commerce and other departments jointly on 30 November 2018, Shang Cai Fa [2018] 486 Hao, hereinafter 'Circular No. 486 of 2018'. Bonded Import and Direct Import are discussed below in Section II.A.

${ }^{8}$ Foreign suppliers conducting CERI have to use e-commerce platforms such as Alibaba's eWTP to sell products to Chinese consumers. For criticism, see below Section III.B.3. The term "e-commerce" is understood to mean the production, distribution, marketing, sale or delivery of goods and services by electronic means. Paragraph 1.3 of the Work Programme on Electronic Commerce, adopted by the General Council on 25 September 1998, WT/L/274, 30 September 1998.

${ }^{9}$ For Pilot Cities, see below Section III. See also \{insert CROSS REFERENCE\} to Douglas Zeng, The Past, Present and Future of Special Economic Zones: Their Evolution and Impact (page number).
} 
Journal of International Economic Law, Volume 24, Issue 2, June 2021, Pages 299320, https://doi.org/10.1093/jiel/jgab018

and expanding the CERI Product Catalogue. ${ }^{10}$ Consequently, the trade volume of CERI in 2020 increased by $16.5 \%$ compared to 2019 levels. ${ }^{11}$

CERI embodies a consumer-oriented model of trade liberalization, which, unlike WTO multilateralism or trade/investment regionalism, is unilateral in nature ('CERI unilateralism'). Compared to WTO multilateralism, CERI unilateralism has been more successful in removing the separation between domestic and foreign markets for Chinese consumers. Beyond reducing custom formalities and tax rates, CERI empowers consumers by treating consumers as 'importers' to minimize behind-the-border trade barriers and by recognising consumers' interests as being diverse rather than homothetic.

This Article analyses CERI under the WTO and FTA law. However, it differs from general scholarship on digital trade, e-commerce, WTO and FTAs. ${ }^{12}$ It focuses on consumer engagement in cross-border e-commerce and the relevant trade challenges that may arise, and further proposes a new concept of consumer-oriented unilateralism and distinguishes it from WTO multilateralism.

Including the Introduction, this Article has four Sections. Section I introduces CERI unilateralism and compares it with WTO multilateralism. Section II highlights CERI Pilot Cities as pioneers for CERI unilateralism. Section III presents the innovative tools for consumer empowerment that CERI unilateralism provides and analyses its legal challenges under the WTO and FTA law. Section VI concludes the Article.

\footnotetext{
${ }^{10}$ For the CERI Product Catalogue, see below Section III.B.1.

${ }^{11}$ See Ministry of Commerce of People's Republic of China, 'Statistics', https://dzswgf.mofcom.gov.cn/sjcx.html (visited 3 March 2021).

12 E.g. Ines Willemyns, 'Agreement Forthcoming? A Comparison of EU, US, and Chinese RTAs in Times of Plurilateral E-Commerce Negotiations', 23 Journal of International Economic Law 221 (2020), at 232-34; Henry Gao, 'Digital or Trade? The Contrasting Approaches of China and US to Digital Trade', 21 Journal of International Economic Law 297 (2018), at 297-321; Rutendo Tavengerwei, 'Using Trade Facilitation to Assist MSMEs in E-Commerce in Developing Countries', 21 Journal of International Economic Law 349 (2018), at 355; Yan Qi, 'Import Duties Relating to Cross-Border E-Commerce in a Chinese Context', 33 Arizona Journal of International and Comparative Law 263 (2016), at 270-71; Rolf H Weber, 'Digital Trade and E-Commerce: Challenges and Opportunities of The Asia-Pacific Regionalism', 10 Asian Journal of WTO and International Health Law and Policy 322 (2015), at 322-47; Brian Bieron and Usman Ahmed, 'Regulating E-Commerce through International Policy: Understanding the International Trade Law Issues of E-Commerce', 46 Journal of World Trade 545 (2012), at 546-70; Anjanette H Raymond and J Benjamin Lambert, 'Technology, ECommerce and The Emerging Harmonization: The Growing Body of International Instruments Facilitating ECommerce and the Continuing Need to Encourage Wide Adoption', 17 International Trade \& Business Law Review 419 (2014), at 434-39.
} 


\section{MODELS OF TRADE LIBERALIZATION}

Through a comparative study, this section aims to demonstrate the different approaches for trade liberalization adopted by WTO multilateralism (Sub-section A) and CERI unilateralism (Sub-section B).

\section{A. WTO multilateralism}

WTO multilateralism relies on treaties to regulate discriminative border and behind-the-border measures. ${ }^{13}$ Products are sold across borders by foreign suppliers to importers. ${ }^{14}$ Consumers do not directly participate in international transactions, since they buy foreign products from the domestic market (see Chart One).

\section{Chart One: WTO Multilateralism}

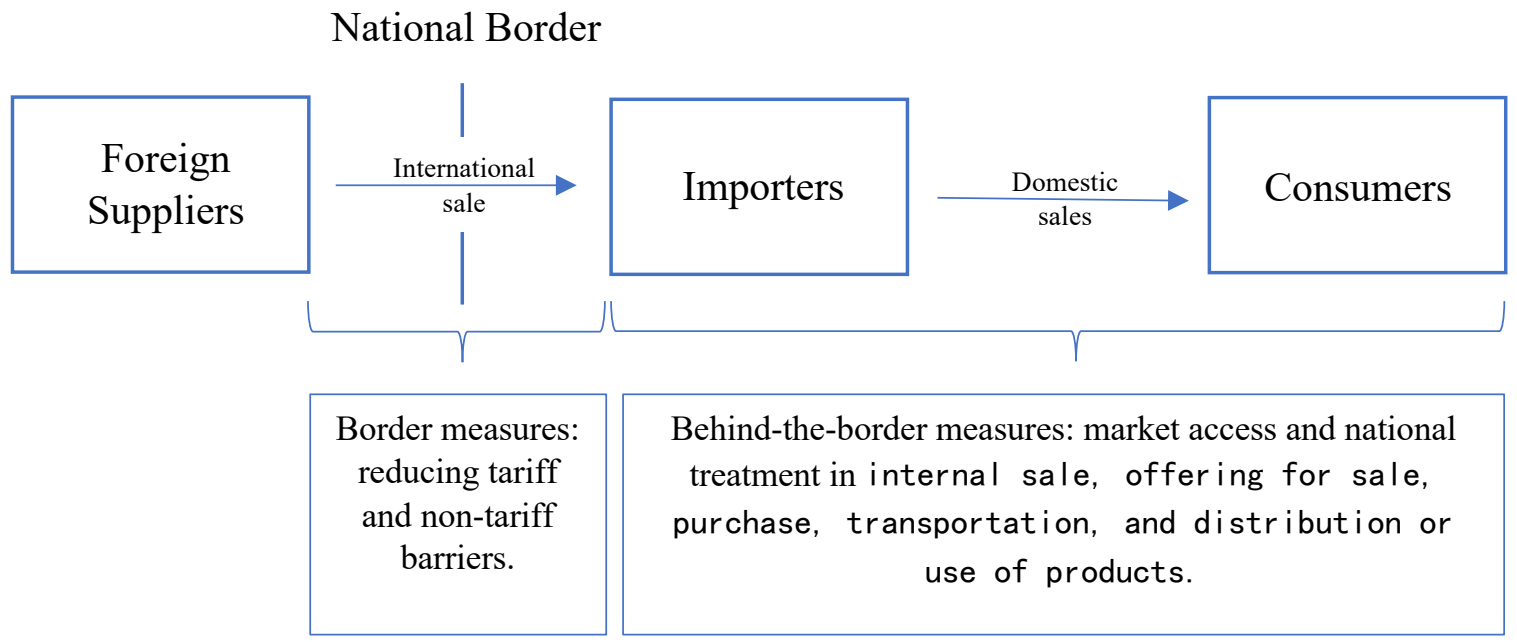

\section{B. CERI consumer-oriented unilateralism}

Cross-border e-commerce transactions may take place between businesses ('B2B') or between businesses and consumers ('B2C'). ${ }^{15} \mathrm{~B} 2 \mathrm{~B}$ e-commerce transactions resemble traditional trade in goods which does not rely on e-commerce technology. ${ }^{16}$ In contrast to

\footnotetext{
${ }^{13}$ Border measures include tariffs imposed on the border and are considered traditional trade restrictive measures. See Marta Wajda-Lichy, 'Traditional Protectionism versus Behind-the-border Barriers in the Post-Crisis Era: Experience of Three Groups of Countries: the EU, NAFTA and BRICS', 7 Journal of International Studies 141 (2014), at 149-150.

14 'Foreign suppliers' in this Article refers to overseas-registered companies that export products to China.

${ }^{15}$ In B2C, 'business' means manufacturers, wholesalers or retailers, and are all generally referred to as 'foreign suppliers' in this Article.

16 Traditional trade in goods without using e-commerce technology is essentially B2B. Therefore, B2B ecommerce imports and other form of traditional trade in goods use the same Customs Supervision Code (0110) in China.
} 
Journal of International Economic Law, Volume 24, Issue 2, June 2021, Pages 299320, https://doi.org/10.1093/jiel/jgab018

B2B transactions, CERI overturns the marketing, sales, and purchasing models between enterprises and consumers, and transforms consumers into importers who are equipped with pre-set options for transportation, payment, and delivery methods. CERI offers a new model of trade liberalization (see Chart Two) with two distinct features. First, based on China's unilateral trade liberalization, CERI reduces far more border and behind-the-border trade restrictive measures compared to WTO multilateralism. ${ }^{17}$ Second, CERI enables consumers to directly participate in international transactions, whereas in WTO multilateralism, international sales are conducted between businesses. CERI also shows greater respect for foreign regulatory systems dealing with product quality and allows consumers to import foreign products that do not comply with Chinese product labelling and quality requirements. This is because CERI treats consumers as diverse individuals who have different needs, and not simply as a homothetic group. ${ }^{18}$ Consequently, CERI empowers consumers in a way different from that of WTO multilateralism. ${ }^{19}$ These two features jointly reduce the separation between Chinese and foreign markets.

\section{Chart Two: CERI Consumer-oriented Unilateralism}

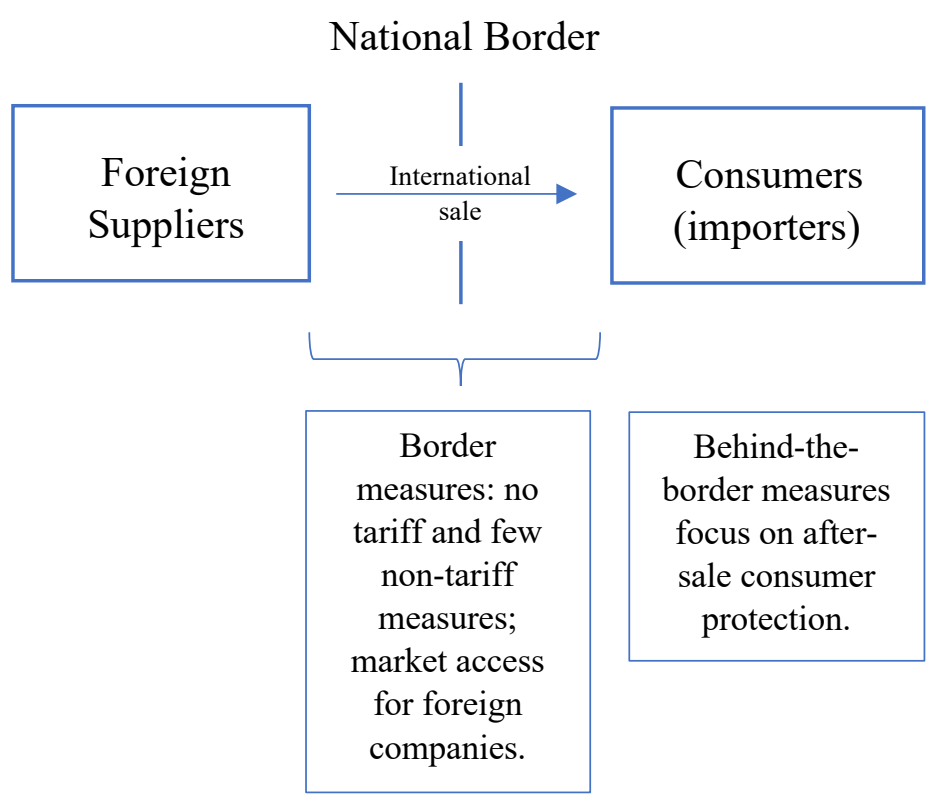

As China's economy has expanded, Chinese consumers have become wealthier. Consumer tastes vary with income, and consequently, over time, Chinese consumers have become more quality- and design-sensitive than price-sensitive. ${ }^{20}$ They have also become increasingly

\footnotetext{
${ }^{17}$ For details, see below Section III.A.

${ }^{18}$ For details, see below Section III.A.2.

${ }^{19}$ Ibid.

${ }^{20}$ Andy Baker, 'Who Wants to Globalize? Consumer Tastes and Labor Markets in a Theory of Trade Policy Beliefs', 49 American Journal of Political Science 924 (2005), at 925 and 936.
} 
Journal of International Economic Law, Volume 24, Issue 2, June 2021, Pages 299320, https://doi.org/10.1093/jiel/jgab018

knowledgeable about high-quality foreign products. However, not all foreign products are available in the Chinese market. Even if they are available, they may be sold at higher prices in China than in the relevant exporting foreign countries. Moreover, while an increasing number of Chinese consumers is interested in purchasing foreign products abroad, they are constrained by international travel costs, visa requirements and recently COVID-19 restrictions. In this context, CERI has prospered in China. In 2017, the CERI value of imports reached USD 8.24 billion, an increase of $75.5 \%$ compared to 2016 levels. ${ }^{21}$ In 2018 , the CERI value of imports was USD 11.45 billion, ${ }^{22}$ and in 2019 , the value was USD 13.37 billion. ${ }^{23}$

\section{PILOT CITIES}

In order to facilitate cross-border e-commerce retail, 5 Chinese Pilot Cities were initially established in August 2012. ${ }^{24}$ Today, there are 87 Pilot Cities geographically spread out across China. Pilot cities not only include large coastal cities but also poverty-stricken counties and even cities in Tibet and Xinjiang autonomous regions. Legally, Pilot Cities are SEZs and function as hubs for foreign suppliers from which products are delivered to Chinese consumers. They are used as 'regulatory sandboxes', that is, special jurisdictions that allow for allow experimentation with this new concept of consumer-oriented unilateralism in Chinese international trade.

\section{A. Special jurisdictions for cross-border e-commerce}

Pilot Cities are special jurisdictions where cross-border e-commerce is subject to a different legal framework than that applicable to other parts of China. ${ }^{25}$ 'Bonded Import', which has become the major form of CERI, can only be conducted in Pilot Cities according to Customs

\footnotetext{
${ }^{21}$ People's Republic of China, 'Three Government Departments Introduce Cross-Border E-commerce Retail Import Supervision Arrangements', http://www.gov.cn/zhengce/2018-12/08/content 5346912.htm (visited 10 March 2021).

${ }^{22}$ General Administration of Customs of the People's Republic of China, 'Press Conference of the GACC relating to Import-Export Levels in 2018', http://fangtan.customs.gov.cn/tabid/612/Default.aspx (visited 23 March 2021).

${ }^{23}$ People's Republic of China, 'Six Ministries including the Ministry of Commerce Further Increase the Number of Pilot Cities', http://www.gov.cn/xinwen/2020-01/17/content 5470348.htm (visited 10 March 2021).

${ }^{24}$ The Notice on Launching National E-commerce Pilot Work, enacted by the National Development and Reform Commission in August 2012, Fa Gai Ban Gao Ji [2012] No. 2218. The 5 Pilot Cities are Zhengzhou, Hangzhou, Chongqing, Shanghai, and Ningbo.

${ }^{25}$ For definitions of SEZ, see FIAS, Special Economic Zone: Performance, Lessons Learned, and Implication for Zone Development (World Bank, 2008) 9-12; Thomas Farole and Gokhan Akinci (eds), Special Economic Zones: Progress, Emerging Challenges, and Future Directions (World Bank, 2011) 1-3.
} 
Supervision Code $1210 .{ }^{26}$ Bonded Import refers to the online purchase of bonded products. ${ }^{27}$ This involves a foreign supplier delivering products in bulk to China, then storing them in approved CERI special customs supervision zones or B type bonded logistics hubs (collectively referred to as 'special customs supervision zones') in Pilot Cities, and selling them to Chinese consumers. ${ }^{28}$ The products are stored under customs supervision and cannot be removed or transferred without permission from customs. After a consumer places an order, customs clearance and delivery from the special customs supervision zones are carried out immediately. Consumers can generally receive their products 2-3 days after placing orders.

Outside Pilot Cities, Bonded Import can be conducted under Customs Supervision Code 1239. ${ }^{29}$ However, cosmetics, infant formula milk powder, medical equipment, special foods and other items which are imported into China for the first time under that Code must obtain an import license, registration or record-filing confirmation. None of these requirements apply to products imported under the 1210 Code via Pilot Cities. ${ }^{30}$ Cross-Border Direct Purchase and Imports ('Direct Import') is another way to conduct CERI that is not limited to Pilot Cities. Direct Import refers to a process in which a Chinese consumer places an order online with a foreign supplier who sends the products across the border directly to the consumer in China. ${ }^{31}$ It is less popular than Bonded Import because it is restricted by the CERI Product Catalogue, which stipulates that some products can only be sold through Bonded Import. ${ }^{32}$ Moreover, consumers using Direct Import generally need to wait longer to receive products delivered from abroad compared to those using Bonded Import. ${ }^{33} \mathrm{~A}$ better consumer purchasing experience is another reason that Bonded Import is preferred. Direct Import is favoured by foreign suppliers

${ }^{26}$ Circular No. 486 of 2018, above $\mathrm{n}$ 7, article 1.1.

${ }^{27}$ Article 5.18 of the Announcement No. 194 of the General Administration of Customs in 2018 on the Supervision of Cross-border E-commerce Retail Import and Export Products, promulgated on 10 December 2018 and effective on 1 January 2019, hereinafter 'Customs Announcement No. 194 of 2018'.

${ }^{28}$ Ibid. The B type bonded logistics hubs are regulated according to the Interim Administrative Measures of the Customs of the People's Republic of China on Bonded Logistics Centres (Type B) (2018 Amendment). Bonded logistics hubs are divided into Type A and B. For differences between the two types of hubs, see Zhihu, 'Comparison between Bonded Logistics Center Type A and B', https://zhuanlan.zhihu.com/p/40726790 (visited 27 December 2020).

${ }^{29}$ Customs supervision Code ' 1239 ' is also referred to as online shopping bonded import mode A. The 1239 Code was added in 2016 as per Announcement [2016] No. 75 of the General Administration of Customs.

${ }^{30}$ Customs Announcement No. 194 of 2018, above n 27, article 3.4.

${ }^{31}$ The Code of Direct Import is ' 9610 '.

${ }^{32}$ As discussed above, Bonded Import can be conducted either through the Customs Supervision Code 1210 or the Customs Supervision Code 1239. The former is restricted to Pilot Cities and the latter can be conducted in special customs supervision zones located in other parts of China. For discussion of the CERI Product Catalogue, see below Section III.B.1.

${ }^{33}$ Ming Wen and Fang Lin, 'Cross-border E-commerce "Difficult Logistics" Problem and Its Countermeasures [Kua Jing Dianzi Shangwu "Wuliu Nan" Wenti Yu Pojie Duice Tansuo]', 28 Mod Bus Xiandai Shangye 37 (2017), at 37. 
Journal of International Economic Law, Volume 24, Issue 2, June 2021, Pages 299320, https://doi.org/10.1093/jiel/jgab018

who are new to the Chinese market; however, they often switch to Bonded Import via Pilot Cities after achieving a stable sales volume in China. ${ }^{34}$

\section{B. The 'import-and-consumption' focus}

Pilot Cities are import-and-consumption-focused, which makes them unique among SEZs in China. First, they are distinct from export processing zones, which focus on manufacturing, storage, trans-shipment, and export. ${ }^{35}$ Second, Pilot Cities are similar to Cross-Border Ecommerce Comprehensive Pilot Zones ('E-commerce Zones') ${ }^{36}$ in that they promote the development of e-commerce in China. However, Pilot Cities focus on CERI, which is specifically related to retail consumption. In contrast, E-commerce Zones are mainly devoted to $\mathrm{B} 2 \mathrm{~B}$ transactions (especially those that are export-related) and have a more comprehensive goal. ${ }^{37}$ Third, the 'import-and-consumption' focus also distinguishes Pilot Cities from Pilot Free Trade Zones ('FTZs') which have a broader scope such as covering trade (import and export, wholesale and retail), investment, and finance. ${ }^{38}$ Nevertheless, because of the geographical overlap of Pilot Cities and most of the E-commerce Zones and FTZs, their policies benefit each other and jointly support the development of e-commerce business in China.

\section{CERI CONSUMER-ORIENTED UNILATERALISM}

The critical difference between CERI and domestic e-commerce retail lies in whether the products are transported across a border. Therefore, customs regulations are the core of CERI governance. This section first analyses why CERI unilateralism empowers consumers in a way

\footnotetext{
${ }^{34}$ China Chamber of International Commerce, Deloitte Research and Ali Research Institute 'Chinese Imported Consumer Goods Market Report', https://www2.deloitte.com/content/dam/Deloitte/cn/ Documents/consumerbusiness/deloitte-cn-comsumer-ali-china-import-consumption-market-report-en-181031.pdf (visited 10 March 2021). ('Deloitte Report'). While foreign suppliers do not need a commercial presence in China to conduct Direct Import or Bonded Import, they would need to hire an agent in China for customs declaration, see Customs Announcement No. 194 of 2018, above n 27, article 8.31.

35 Patrick Neveling, 'Export Processing Zones, Special Economic Zones, and the Long March of Capitalist Development Policies during the Cold War' in Leslie James and Elisabeth Leake (eds), Decolonization and the Cold War: Negotiating Independence (London: Bloomsbury Publishing, 2015) 77.

${ }^{36}$ Reply on the Approval of 46 Cities and Regions to Establish Cross-Border E-commerce Comprehensive Pilot Zones, Guo Han [2020] 47 Hao, issued on 27 April 2020 by the State Council and effective on the same date.

${ }^{37}$ For the comprehensive goals of E-commerce Zones, see Article 2 of the Official Reply of the State Council on Approving the Establishment of Cross-Border E-commerce Comprehensive Pilot Zones in Tianjin and Other 11 Cities, Letter No. 17 [2016], issued on 12 January 2016 by the State Council.

${ }^{38}$ E.g. People's Republic of China, 'Central Committee of the Communist Party of China and the State Council issue of its overall plan for the construction of Hainan Free Trade Port', http://www.gov.cn/zhengce/202006/01/content 5516608.htm (visited 10 January 2020).
} 
Journal of International Economic Law, Volume 24, Issue 2, June 2021, Pages 299320, https://doi.org/10.1093/jiel/jgab018

different from WTO multilateralism and then discusses challenges that CERI is confronted with.

\section{A. CERI consumer empowerment}

Both WTO multilateralism and CERI unilateralism aim to eliminate border and behind-theborder trade barriers. However, CERI exempts tariffs, reduces internal tax, and simplifies customs formalities more successfully than WTO multilateralism. Further, as opposed to the WTO, CERI reinforces consumer protection by largely respecting each individual consumer's preference in product quality governance. Consequently, consumers have easier, cheaper, and better access to foreign products as direct participants in international sales in CERI.

\section{Tariff exemption and reduced internal tax}

The distinctive feature of CERI unilateralism is that every Chinese national can enjoy tariff exemption and tax reduction for CERI products purchased below the monetary limits on a single transaction and the annual expenditure. The limit for a single CERI transaction is RMB 5,000 (USD 728), and the limit for the annual expenditure is RMB 26,000 (USD 3,787). ${ }^{39}$ For products imported within the single transaction and annual limits, the tariff rate for CERI is $0 \%$ and the import value-added tax and consumption tax are levied at $70 \%$ of the statutory taxable amount. ${ }^{40}$ For any transaction exceeding the limits on a single transaction or the annual expenditure, or a single indivisible product whose duty-paid price is more than RMB 5,000 (USD 728), tax is levied on the full amount as per the rules governing traditional trade. ${ }^{41}$ Products imported via CERI are generally cheaper than those imported through traditional trade (see Table One).

Table One: Tariff and internal tax

\begin{tabular}{|c|c|c|c|c|c|}
\hline \multirow{2}{*}{ Product } & MFN & VAT & Consumption & $\begin{array}{c}\text { Traditional } \\
\text { Trade Total }\end{array}$ & $\begin{array}{c}\text { CERI Total } \\
\text { Tax (\%) } \\
\end{array}$ \\
& Tariff (\%) & $(\%)$ & Tax (\%) & Tax (\%) & \\
\hline
\end{tabular}

\footnotetext{
${ }^{39}$ Article 1 of the Circular on the Improvement of CERI Tax Policies, Cai Guan shui [2018] No. 49 Hao, enacted by the Ministry of Finance on 29 November 2018 and effective on 1 January 2019.

${ }^{40}$ Articles 1 and 3 of the Notice of Tax Policies for Cross-border E-commerce Retail Imports, Cai Guan Shui [2016] No. 18, enacted by the Ministry of Finance and other departments jointly on 24 March 2016 and effective on 8 April 2016.

${ }^{41}$ Circular on the Improvement of CERI Tax Policies, above n 39, article 2.
} 
Journal of International Economic Law, Volume 24, Issue 2, June 2021, Pages 299320, https://doi.org/10.1093/jiel/jgab018

\begin{tabular}{|c|c|c|c|c|c|}
\hline $\begin{array}{c}\text { Baby formula } \\
\text { milk powder }\end{array}$ & 15 & 13 & 0 & $\mathbf{2 9 . 9 5}$ & $\mathbf{9 . 1}$ \\
\hline
\end{tabular}

Source: data on https://www.jd.hk/service/taxrate.html (visited 3 February 2021)

\section{Simplify customs formalities and re-conceptualize consumer protection}

The WTO allows an importing state to require foreign manufacturers to convey truthful and accurate information about products by using marks of origin, ${ }^{42}$ geographic indications, ${ }^{43}$ and other labelling requirements. ${ }^{44}$ However, these types of regulatory measures would have to be formulated in a non-discriminatory and non-protectionist manner. Article 2.2 of the Agreement on Technical Barriers to Trade ('TBT Agreement') also makes the protection of consumers against deceptive practices a legitimate objective that may be pursued by non-tariff trade barriers. ${ }^{45}$ For CERI, the quality, safety, and labelling requirements imposed by Chinese law are unilaterally waived. ${ }^{46}$ As such, labelling for CERI products is determined by the law of the exporting countries. Foreign suppliers should inform Chinese consumers of any differences in quality standards between the exporting countries and China by providing a risk notification letter on, for example, the product ordering webpage. ${ }^{47}$ The letter should also indicate that products may come with foreign-language labels, with Chinese-language labels only available online. ${ }^{48}$ Therefore, CERI unilateralism minimizes the possibility that an importing State may use the quality and labelling requirements as disguised trade barriers.

Chinese customs requires products that are imported into China for the first time to complete licensing, registration or record-filing procedures. CERI products are exempted from these requirements. ${ }^{49}$ For example, infant formula must be registered with the relevant food safety

\footnotetext{
42 Article IX:2 of GATT.

${ }^{43}$ E.g. article 22.2(a) of the Agreement on Trade-Related Aspects of Intellectual Property Rights, 15 April 15 1994, Marrakesh Agreement Establishing the World Trade Organization, Annex 1C, 1896 U.N.T.S. 299,33 I.L.M. 1197 (1994). For cases, see Panel Report, European Communities-Protection of Trademarks and Geographical Indications for Agricultural Products and Foodstuffs, Complaint by the United States, WT/DS174/R, adopted 20 April 2005.

${ }^{44}$ E.g. articles XI and XX of GATT 1994. For cases on labelling requirements, see e.g. Panel Report, European Communities-Trade Description of Sardines, WT/DS231/R, adopted 23 October 2002, paras 4.60, 7.122, and 7.139; Panel Report, United States-Measures Concerning the Importation, Marketing and Sale of Tuna and Tuna Products, WT/DS381/R, adopted 13 June 2012, paras 4.176 and 7.620.

${ }^{45}$ Article 2.2 of the TBT Agreement.

${ }^{46}$ Circular No. 486 of 2018 , above n 7, article 4.1.3.1.

${ }^{47} \mathrm{Ibid}$, at articles 4.1 .3 and 1.3.

${ }^{48} \mathrm{Ibid}$, at articles 4.1.3 and 1.3.

${ }^{49}$ Customs Announcement No. 194 of 2018, above n 27, article 3.4. Here, 'CERI products' refers to products imported by Bonded Import via the Pilot Cities or Direct Import. Products imported by Bonded Import outside of Pilot Cities are not exempted by article 3.4. See above Section II.A.
} 
supervision and administration of the State Council according to Chinese Food Safety Law. ${ }^{50}$ This registration often takes 2 to 4 years and the formula sold in foreign markets needs to be modified to comply with Chinese standards. ${ }^{51}$ However, these requirements do not apply to products imported through CERI. There are only two exceptions to this general exemption. The first exception is for products imported from epidemic areas that have been explicitly banned by relevant Chinese government departments. ${ }^{52}$ The second is for products that have major quality and safety risks, and for which a relevant risk emergency response has been initiated by relevant government departments. ${ }^{53}$

Overall, WTO multilateralism allows importing states to impose domestic labelling and product quality standards, as well as other measures to protect consumers, on the condition that these measures are not used as disguised trade barriers. ${ }^{54}$ In contrast, CERI unilateralism protects consumers by giving them the right to choose products made under standards different from those in China. By allowing consumers to opt out of ordinary Chinese law, CERI unilateralism introduces foreign regulatory systems to China. In the case of WTO multilateralism, all consumers in an importing state are presumed to accept the labelling and product quality standards imposed by the importing state. However, compared to producers, consumers are less well organized and hence have less influence in the government's standardmaking process. ${ }^{55}$ Even if consumer organizations have a strong lobbying power, the labelling and product quality standards represent the preference of the majority of consumers rather than each individual consumer. ${ }^{56}$ WTO multilateralism treats consumers as a homothetic group rather than considering their individual needs. CERI unilateralism, on the other hand, acknowledges that consumers are diverse, and that their needs are not homothetic. ${ }^{57} \mathrm{By}$

\footnotetext{
${ }^{50}$ Articles 74 and 81 of Chinese Food Safety Law, adopted at the $7^{\text {th }}$ meeting of the Standing Committee of the Eleventh National People's Congress on 28 February 2009, amended on 24 April 2015; Articles 2 and 7 of Administrative Measures for the Registration of Infant and Young Children Formula Milk Powder Formula, promulgated by the China Food and Drug Administration on 6 June 2016 and entered into force on 1 October 2016. The "relevant food safety supervision and administration of the State Council" has evolved: (1) up until 2013: the State Food and Drug Administration; (2) from 2013 to 2018: the China Food and Drug Administration; (3) from 2018 to today: the Administration for Market Regulation.

${ }^{51}$ Deloitte Report, above n 34, at 27.

52 Ibid.

${ }^{53}$ Ibid.

${ }^{54}$ Carlos Lopez-Hurtado, 'Social Labelling and WTO Law', 5 Journal of International Economic Law 719 (2002), at $734-45$.

${ }^{55}$ Anne van Aaken and Jürgen Kurtz, 'Beyond Rational Choice: International Trade Law and The Behavioral Political Economy of Protectionism', 4 Journal of International Economic Law 22 (2019), at 601-2.

${ }^{56}$ See e.g. Ilona Cheyne, 'Proportionality, Proximity and Environmental Labelling in WTO Law', 12 Journal of International Economic Law 927 (2009), at 930-34.

${ }^{57}$ See Baker, above n 20, at 924-926.
} 
Journal of International Economic Law, Volume 24, Issue 2, June 2021, Pages 299320, https://doi.org/10.1093/jiel/jgab018

respecting each individual consumer's right to choose labelling and product quality standards, CERI unilateralism empowers consumers.

Arguably, the labelling and product quality requirements that exist in China are for consumer protection purposes. Economic theory suggests that removing these requirements could lead to a 'race to the bottom', where standards are abandoned in order to attract customers with low prices. However, this argument should be qualified in CERI. This is because CERI does not remove labelling and product quality requirements. Rather, CERI allows products complying with foreign product labelling and quality requirements to be imported into China. Importantly, the economic scholarship also shows that consumers will be less price sensitive and more quality sensitive when they become wealthier. ${ }^{58}$ China has one of the highest numbers of middle- and high-income consumers in the world. ${ }^{59}$ Such consumers use CERI to buy foreign products because they want to enjoy high-quality products made in accordance with the standards of developed countries. Further, for products like baby formula, even poor Chinese families will try their best not to sacrifice product quality for price. Suppose that baby formula products complying with either Australian or Iraqi quality standards are both available on the CERI market, there is no doubt that Chinese consumers are willing to pay more for the former. Market competition and consumers' taste will gradually lead to a decline in products made in accordance with foreign, but lower than Chinese, standards.

The real consumer protection concern in CERI is how to eliminate fake foreign products allegedly made in accordance with the standards of developed countries (e.g. fake Australian baby formula products). CERI unilateralism does not necessarily move all the regulatory risk of fake products to consumers. First, China establishes a carrot-and-stick credit system for foreign suppliers as well as other CERI business participants to incentivize them to provide high-quality products. Foreign suppliers are subject to Chinese customs credit management. ${ }^{60}$ China imposes different customs clearance management procedures based on the credit levels of a foreign supplier. ${ }^{61}$ Suppliers that are recognized as trustworthy by Chinese customs can enjoy simplified customs clearance procedures. ${ }^{62}$ Suppliers that are recognized as untrustworthy by customs are subject to strict supervision measures. ${ }^{63}$ Customs will publicize the names of trustworthy and untrustworthy suppliers and spread such information using its

\footnotetext{
${ }^{58}$ Ibid, at 925, 936.

59 E.g. China Briefing News, 'Who Make Up China's Middle Class? We Asked 5 Simple Questions', https://www.china-briefing.com/news/chinas-middle-class-5-questions-answered/ (visited 28 October 2020).

${ }^{60}$ Circular No. 486 of 2018, above n 7, article 4.5.3.

${ }^{61}$ Ibid.

${ }^{62}$ Ibid.

${ }^{63}$ Ibid.
} 
website, other websites such as 'Credit China', and the national corporate credit information disclosure system. ${ }^{64}$ Second, WTO law requires products to comply with the rules on sanitary and phytosanitary measures ('SPS measures'), and prohibits a member state from using SPS measures as disguised trade barriers. ${ }^{65}$ China also imposes SPS measures (such as inspection and quarantine) on CERI products and their containers and packaging. ${ }^{66}$ Foreign suppliers should not export to China products that endanger public health, safety and biosecurity. ${ }^{67}$ Last but not least, CERI and other Chinese laws impose a great deal of regulatory responsibility on e-commerce platforms. Article 27 of the Chinese E-commerce Law provides that where a product supplier applies to an e-commerce platform provider to use the platform to sell products, the latter shall ask the former to submit information such as identity, address, contact information, and administrative license. ${ }^{68}$ The platform should verify the information submitted and periodically review and update the information. ${ }^{69}$ Article 44.2 of the Chinese Consumer Law provides that if an e-commerce platform knows, or should have known, that a product supplier using its platform is infringing upon consumers' rights and interests, and does not take any steps to stop such infringement, the platform provider, with the supplier, will be jointly and severally liable to the consumers. ${ }^{70}$ Article 38.1 of the E-commerce Law particularises a specific circumstance of violation of the Consumer Law: where an e-commerce platform knows, or should have known, that the products provided by a supplier over its platform fail to meet the requirements for the protection of personal and property safety, and does not take any steps to remedy this failure, the platform and the product supplier bear joint and several liability for the failure. ${ }^{71}$ The steps that could be taken include urging foreign suppliers to recall, repair or report their products when product quality and safety problems occur, ${ }^{72}$ suspending online sale of the relevant products, or simply ceasing to provide services for the foreign suppliers. Article 38.2 of the Chinese E-commerce Law focuses on goods or

64 Ibid.

${ }^{65}$ Sara Pardo Quintillan, 'Free Trade, Public Health Protection and Consumer Information in the European and WTO Context', 33(6) Journal of World Trade 147 (1999), at 153-193.

${ }^{66}$ Customs Announcement No. 194 of 2018, above n 27, article 3.5.

${ }^{67} \mathrm{Ibid}$, at article 8.26.3.

${ }^{68}$ Chinese E-commerce Law, adopted at the Fifth Session of the Standing Committee of the $13^{\text {th }}$ National People's Congress of China on 31 August 2018 and effective on 1 January 2019, Order No. 7 of the President of China, article 27.1.

${ }^{69}$ Ibid.

${ }^{70}$ Article 44.2 of the Chinese Consumer Law, adopted at the Fourth Meeting of the Standing Committee of the Eighth National People's Congress on 31 October 1993, effective on 1 January 1994, amended on 25 October 2013.

${ }^{71}$ China E-commerce Law, above n 68, article 38.1.

${ }^{72}$ Circular No. 486 of 2018, above n 7, article 4.2.6; Article 2 of the Notice No. 45 of 2020 on Supervisions of Product Return in Cross-Border E-commerce Retail Import and Export, Gonggao [2020] 45 Hao, issued by the General Administration of Customs on 28 March 2020 and effective on the same date ('Notice No. 45 of 2020'). 
Journal of International Economic Law, Volume 24, Issue 2, June 2021, Pages 299320, https://doi.org/10.1093/jiel/jgab018

services related to consumers' lives and health. It imposes a general obligation on e-commerce platforms to review the qualifications or certificates of suppliers using the platforms to sell such goods or services. ${ }^{73}$ Importantly, taking the above described steps does not exempt the platforms from this general obligation. E-commerce platforms bear joint and several liability with product suppliers if the platforms fail to review the qualifications or certificates of the suppliers or fail to fulfil the safety guarantee obligations to consumers, thereby causing harm to them. ${ }^{74}$ Furthermore, in case of disputes between consumers and foreign suppliers, the platforms must compensate consumers first. ${ }^{75}$ Therefore, the platforms play a critical role in sharing the regulatory risk with consumers.

In addition, products that are eligible for importation through CERI can still be traded through traditional routes. The difference is that products traded through traditional routes must comply with Chinese laws such as product quality and labelling, unlike those traded via CERI. The issue is whether China can justify the WTO-consistency of maintaining regulatory differences for the same products only because they are imported through a different mode. These regulatory differences should not be considered as a trade barrier. This is because CERI regulation is China's unilateral trade liberalization, an additional commitment to those it has with the WTO and in its FTAs. The Appellate Body in Japan-Alcoholic Beverages II held that Article III of GATT 1994 obliged member states to provide equality of competitive conditions for imported products in relation to domestic products. ${ }^{76}$ Although China waives the labelling and quality requirements for foreign products imported via CERI, China does not violate Article III by imposing these requirements on products imported through traditional routes. This is because all Chinese domestic products must comply with Chinese labelling and quality laws. Moreover, CERI regulation is non-discriminatory in nature, applying to products from all countries. Consumers are the final purchasing decision makers . Therefore, the regulatory differences for foreign products imported via different modes unlikely violate China's WTO and FTA commitments.

\footnotetext{
${ }^{73}$ Chinese E-commerce Law, above n 68, para 2 of article 38.

${ }^{74}$ See Jie (Jeanne) Huang, 'Internet (Un)Immunity: Where Does China Stand?', 7(2) Asian Journal of Law and Society 345 (2020), at 362-366.

${ }^{75}$ Circular No. 486 of 2018 , above n 7, article 4.2.5.

${ }^{76}$ Page 16 of WTO Appellate Body Report, Japan-Taxes on Alcoholic Beverages (Japan-Alcoholic Beverages II), WT/DS8/AB/R, WT/DS10/AB/R, WT/DS11/AB/R, adopted 1 November 1996.
} 


\section{Decrease behind-the-border trade barriers}

Article III of GATT 1994 provides that 'laws, regulations and requirements affecting the internal sale...transportation, distribution or use of products... should not be applied to imported or domestic products so as to afford protection to domestic production' (emphasis added). ${ }^{77}$ Article III applies to behind-the-border measures, which should not discriminate between like domestic and foreign products so as to afford protection to the former. ${ }^{78}$ In CERI, behind-the-border measures focus on consumer protection. First, foreign suppliers are required to establish a product quality mechanism and to trace the origins of their products. ${ }^{79}$ Second, foreign suppliers must assume responsibility for quality and safety. ${ }^{80}$ Notably, e-commerce platforms must establish a consumer dispute resolution mechanism and actively assist consumers in safeguarding their legal rights. ${ }^{81}$ Third, foreign suppliers must allow a Chinese consumer to return a product within 7 days of receipt without giving a reason. ${ }^{82}$ If the returned product meets the requirements for secondary sales and arrives in the relevant location within 45 days from the date of customs clearance, the foreign supplier or its agent must help the consumer apply to Chinese Customs for a tax refund and a resetting of the consumer's cumulative amount of personal annual transactions. ${ }^{83}$ The first measure only applies to foreign products. However, it is not likely to violate the national treatment standard because foreign products in CERI are exempt from complying with Chinese laws for product quality and labelling, and the product quality traceability mechanism has a soft law quality. The second and the third measures are origin neutral as they also apply to domestic products and suppliers.

From a business perspective, CERI is akin to traditional duty-free shops because both involve duty-free shopping with per capita limits on single transactions and annual expenditure. However, different from traditional duty-free shops, in the legal sense, CERI opens the door to consumer-oriented unilateralism in international trade law from three important aspects. First, duty-free shops still follow the model of WTO multilateralism (Chart One in above Section I), because foreign products are imported into China by importers (duty-free shops) from whom Chinese consumers buy products. In contrast, CERI unilateralism is based on a completely different model (Chart Two in above Section I), which allows consumers to directly purchase

\footnotetext{
77 Article III:1 of GATT 1994. See Ad Article III of GATT 1994 (providing the dividing line between internal and border measures). See WTO Appellate Body Report, Korea-Measures Affecting Imports of Fresh, Chilled and Frozen Beef, WT/DS161/AB/R, WT/DS169/AB/R, adopted 10 January 2001, para 137.

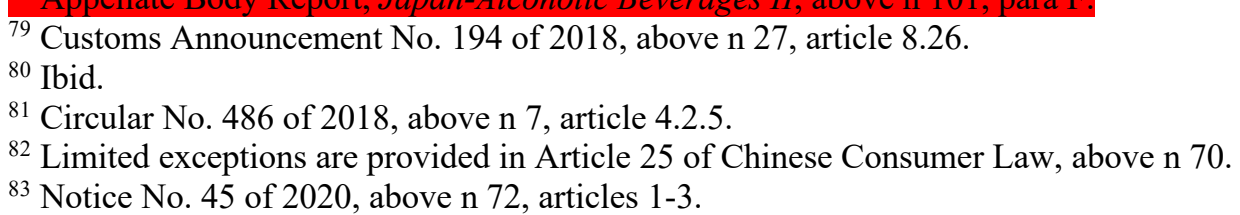


Journal of International Economic Law, Volume 24, Issue 2, June 2021, Pages 299-

320, https://doi.org/10.1093/jiel/jgab018

products from foreign suppliers. Unlike traditional duty-free shops, CERI unilateralism enables consumers to directly participate in international trade. This is significant because existing international trade law rarely regulates the Business-to-Consumer retail trade. For example, WTO law has been criticized for its lack of consumer protection. ${ }^{84}$ The UN Convention on Contracts for the International Sale of Goods does not apply to consumer contracts. ${ }^{85}$ Therefore, CERI unilateralism provides an important new perspective for the existing international trade law. Second, equating CERI with traditional duty-free shops ignores the fact that e-commerce creates more consumer benefits than traditional shopping, especially for consumers who live far away from large cities, where duty-free shops are often located. CERI is an online business that allows for products to be delivered to any part of China from Pilot Cities. Duty-free shops, however, are brick-and-mortar and can only be found in major airports and on Hainan Island in China. ${ }^{86}$ Traditional duty-free shops do not require foreign suppliers to establish a product quality mechanism and trace the origins of their products, as is required in CERI. The CERI Product Catalogue also provides many more products than those available in duty-free shops. ${ }^{87}$ Third, CERI provides Chinese market access to foreign small- and medium- sized suppliers, which is significant because these suppliers may otherwise not be able to satisfy Chinese labelling or product quality regulations. In contrast, traditional duty-free shops normally focus on high-end luxury brands and unlikely improve Chinese market access for small- and medium- sized foreign enterprises.

\section{B. Challenges}

Although CERI unilateralism empowers consumers differently from WTO multilateralism, CERI regulatory measures should not be exempted from WTO and FTA law. CERI is confronted with three main challenges: a positive list of products, upper limits on the monetary value of a single transaction and the annual expenditure of a consumer, and market access for foreign companies.

\footnotetext{
${ }^{84}$ See generally Rolland Sonia, 'Are Consumer-Oriented Rules the New Frontier of Trade Liberalization', 55 Harvard International Law Journal 361 (2014).

${ }^{85}$ Article 2(a) of the UN Convention on Contracts for the International Sale of Goods, signed on 11 April 1980 and effective on 1 January 1988.

${ }^{86}$ See generally The Notice on Increasing the Number of CERI Pilot Cities issued by the Ministry of Commerce, Development and Reform Commission, Ministry of Finance, General Administration of Customs, State Administration of Taxation, and State Administration of Market Supervision on 17 January 2020, Shang Cai Fa [2020] 15 Hao.

${ }^{87}$ For the CERI Product Catalogue, see below Section III.B.1.
} 


\section{CERI product catalogue}

CERI is limited to products listed in the CERI Product Catalogue, which currently contains 1,413 products listed by 8 -digit HS codes with brief product descriptions. ${ }^{88}$ The products in the Catalogue range from food to machines, include agricultural and industrial products, and contain raw, intermediary and final products. It is a positive list, and therefore, only listed products can be sold to Chinese consumers via CERI. The import restrictions applicable to such products are stated in the additional information column in the Catalogue - although most of the products are not subject to any restrictions. There are five main categories of restrictions. First, 91 products can only be sold to Chinese consumers via Bonded Import. It is unclear how and why those products were selected. Second, certain products in the Catalogue (e.g. eggs with HS Code 04079090) are subject to other import restrictions such as the Import and Export Wild Fauna and Plant Species Commodity List. ${ }^{89}$ Third, 13 agricultural products are subject to quantitative restrictions. For example, every Chinese consumer's overall annual import of wheat fine powder or grain (HS Code 1101000) and wheat coarse powder or grain (HS Code 11031100) should not exceed 20 kilograms. Fourth, although CERI is a retail trade for household consumption, only some products in the Catalogue are required to be for household use only. ${ }^{90}$ Interestingly, products such as metal surface pickling agent and solder powder (HS Code 38101000), may not necessarily be used for household consumption but are still included in the Catalogue. Fifth, for the 20 medicine or medical equipment related products contained in the Catalogue, if they are subject to other medical import regulations, those regulations prevail over the Catalogue. Notably, more types of foreign medicine are likely to be imported via CERI according to the China (Beijing) Pilot Free Trade Zone Overall Plan released on 30 August 2020.91

The CERI Product Catalogue may raise the issue of Most Favoured Nation (MFN) treatment. This is because products under the CERI scheme are not subject to tariffs, tax or domestic regulations, while those imported through the normal channels have to comply with all such

\footnotetext{
${ }^{88}$ Notice to Adjust and Expand the CERI Product Catalogue, jointly issued by the Ministry of Finance and twelve other departments on 24 December 2019 and effective on 1 January 2020.

${ }^{89}$ Other import restrictions can be found in the Import Management List of Cryptography Product and Equipment Containing Cryptography Technology, the List of Strictly Restricted Toxic Chemical Products, the Import and Export Management List of Pesticide, and the Dual-use (Nuclear) Items and Technology Import and Export License Management Catalogue.

${ }^{90}$ E.g. Polyvinyl chloride boards with HS Code 39204900 are limited to the use of household plastic wrap.

${ }^{91}$ People's Republic of China, 'Article 3.1.2. of China (Beijing) Pilot Free Trade Zone Overall Plan', http://www.gov.cn/zhengce/content/2020-09/21/content 5544926.htm (visited 7 March 2021).
} 
Journal of International Economic Law, Volume 24, Issue 2, June 2021, Pages 299320, https://doi.org/10.1093/jiel/jgab018

requirements. Article I:1 (MFN) of GATT 1994 bans both de jure and de facto discrimination. ${ }^{92}$ First, de Jure discrimination requires the wording of a member state's regulation to be 'originneutral'. In the CERI Product Catalogue, Frozen Norwegian Sea Crawfish (HS Code 03061500) is not 'original-neutral' because it specifies the country of origin of the product: Norway. Other product descriptions in the Catalogue do not specify the country of origin. Moreover, other CERI regulations do not give benefits to a (or any) specific country so they do not create de jure discrimination. Second, in terms of de facto discrimination, the Appellate Body in Canada-Autos held that Canada breached Article 1:1 because, in practice, a motor vehicle imported into Canada was granted import duty exemption only if it originated in one of a small number of countries in which an exporter of motor vehicles was affiliated with a manufacturer/importer in Canada that had been designated as eligible to import motor vehicles duty-free under relevant Canadian laws. ${ }^{93}$ In CERI, foreign suppliers have to sell products on Chinese e-commerce platforms, ${ }^{94}$ and it is unclear whether those platforms may, potentially due to Chinese government pressure, sell products originating only from certain countries. If the Chinese government requires the selling of products which originate only from certain countries in the CERI scheme, it violates Article 1:1. However, no violation occurs if the platforms sell products only from certain countries due to commercial reasons (e.g. products from certain countries are commercially more profitable than others, or Chinese consumers, because of their private consumption habits, prefer buying products made in certain countries). At this stage, it is unclear whether CERI regulations in practice really only provide benefits to imports from a small number of countries, or whether the Chinese government imposes pressure on e-commerce platforms to sell products only from certain countries (or not sell products from certain countries). Nevertheless, China should make the procedure surrounding the creation of the CERI Catalogue more transparent because it is unclear what the criteria for inclusion are. The limited products in the Catalogue and the lack of transparency regarding its making and development restrict CERI unilateralism.

\section{Quota}

Article XI:1 of GATT 1994 provides that '[n]o prohibitions or restrictions other than duties, taxes or other charges' on imports and exports of goods can be 'made effective through

\footnotetext{
${ }^{92}$ WTO Appellate Body Report, Canada-Certain Measures Affecting the Automotive Industry, WT/DS139/AB/R, WT/DS142/AB/R, adopted 19 June 2000, para 78.

${ }^{93} \mathrm{Ibid}$, at para 80.

${ }^{94}$ For discussion of the restriction requiring foreign suppliers in CERI to conduct sales on third-party e-commerce platforms, see below Section III.B.3.
} 
quotas... or other measures'. In Japan-Trade in Semi-conductors, the Panel Report confirmed the broad scope of the term 'measure' in Article XI:1, holding that it extended beyond laws and regulations. ${ }^{95}$ The term was found to include 'any measure' which restricted the exportation or importation of goods, irrespective of the legal status of the said measure. ${ }^{96}$ One measure, called a 'quota', was presumed to cause nullification or impairment 'whether or not it actually impeded imports'. ${ }^{97}$ In CERI, the quantitative restriction on a certain product that a Chinese national may purchase in the Catalogue ${ }^{98}$ is a quota. However, the quota in the Catalogue is essentially a tariff rate quota, meaning that products purchased within the quota enjoy the tariff exemption offered by CERI unilateralism, whereas products arriving in China through traditional trade routes that are over the quota are subject to a high secondary tariff (i.e. the most-favoured-nation tariff). The unadopted 1994 panel report on 'EEC-Import Regime for Bananas' considered whether the establishment of a tariff quota on bananas was inconsistent with Article XI. ${ }^{99}$ In this case, the EEC measure permitted the import of bananas under one tariff rate up to a specified amount, with anything beyond that amount attracting a higher tariff rate. ${ }^{100}$ The Panel noted that 'the schedules of concessions of many contracting parties provided for tariff quotas and that the CONTRACTING PARTIES had never found tariff quotas, as such, to be "restrictions" within the meaning of Article XI:1'. ${ }^{101}$ The Panel concluded that the tariff quota was not inconsistent with Article XI:1. ${ }^{102}$ This conclusion should apply to the quantitative restriction in the CERI Catalogue, which does not violate Article XI:1. Nevertheless, the quantitative restriction on a certain product that a Chinese national may purchase in the Catalogue differs from the EEC tariff rate quota on imports of bananas in one important way. The former is not a country-specific quota, while the latter is. The EEC quota was for its African, Caribbean, and Pacific ('ACP') former colonies. ${ }^{103}$ The EEC had to request a waiver of its non-discrimination obligations under Article XXV:5 of GATT and Article IX

\footnotetext{
95 Panel Report, Japan-Trade in Semi-conductors, L/6309 - 35S/116, adopted 4 May 1988, paras 104-109.

${ }^{96}$ Ibid. WTO case-law subsequently confirmed that Article XI applies only to governmental measures in Panel Report, Argentina - Measures Affecting the Export of Bovine Hides and the Import of Finished Leather, WT/DS155/R 666, adopted 16 February 2001.

${ }^{97}$ Panel Report, Japanese Measures on Imports of Leather, L/5623 - 31S/94, adopted 15/16 May 1984, paras 4748, 53, 55; Panel Report, European Economic Community-Payments and Subsidies to Processors and Producers of Oilseeds and Related Animal-Feed Proteins, L/6627 - 37S/86, adopted 25 January 1990, para 150, referring to Panel Report, Japanese Measures on Imports of Leather, L/5623 - 31S/94, adopted 15/16 May 1984.

98 See above Section III.B.1.

99 Panel Report, EEC-Import Regime for Bananas, DS38/R, dated 11 February 1994.

${ }^{100} \mathrm{Ibid}$, at para 138.

101 Ibid.

102 Ibid.

${ }^{103}$ Daniel Marinberg, 'GATT/WTO Waivers: Exceptional Circumstances as Applied to the Lomé Waiver', 19 Boston University International Law Journal 129 (2001), at 129.
} 
of the WTO Agreement. ${ }^{104}$ The waiver was eventually granted to the EEC in order to settle the Bananas dispute at the 2001 Ministerial Conference in Doha. ${ }^{105}$ While the EEC was permitted to maintain its tariff quota, it was required to promptly enter into consultations with any interested member State to remedy the discriminatory effect of the quota. ${ }^{106}$ In contrast, the CERI quantitative restriction is not country specific; therefore, China does not need to request a waiver as EEC was required.

The upper monetary limits on a single transaction and the annual expenditure of a Chinese national in CERI are not quotas on a certain product ${ }^{107}$ because the limits are imposed on Chinese consumers who can freely decide what products to buy. The limits are not 'other measures' under Article XI:1 for three reasons. First, they do not constitute import prohibitions or restrictions. The Panel on United States Manufacturing Clause examined the US law that prohibited, with certain exceptions, the importation or public distribution in the US of copies of a work consisting predominantly of copyrighted literary material in English that had not been produced in the US or Canada. ${ }^{108}$ The Panel held that the US law was inconsistent with Article XI:1. ${ }^{109}$ In contrast, CERI allows consumers to buy products beyond the abovedescribed upper monetary limits if they are willing to pay the normal tariff. Therefore, the limits in CERI do not constitute import prohibitions. The limits might be seen as a 'restriction' within the meaning of Article XI:1 in that they impose a condition that may have a limiting effect on imports due to consumers being unwilling to pay the regular price. This argument is questionable, however, because the monetary limits essentially function as a tariff quota and can be justified by EEC-Import Regime for Bananas. Second, the limits do not provide minimum price systems for imports because they are upper, not lower, limits. ${ }^{110}$ Third, the limits are not related to state-trading operations, import restrictions for the balance of payment, or retaliation. ${ }^{111}$

\footnotetext{
${ }^{104}$ Ibid, at $130-31$.

${ }^{105}$ World Trade Organization, 'European Communities-transitional regime for the EC autonomous tariff rate quotas on imports of bananas', https://www.wto.org/english/thewto e/minist e/min01 e/mindecl ec bananas e.htm (visited 7 March 2021). 106 Ibid.

${ }^{107}$ Rüdiger Wolfrum, Peter-Tobias Stoll and Anja Seibert-Fohr, WTO - Technical Barriers and SPS Measures (Brill Nijhoff, 2007) 51.

${ }^{108}$ Panel Report, The United States Manufacturing Clause, L/5609 - 31S/74, adopted 15/16 May 1984, paras 1011.

${ }^{109}$ Ibid, para 42(i).

110 Panel Report, EEC - Programme of Minimum Import Prices, Licences and Surety Deposits for Certain Processed Fruits and Vegetables, L/4687 - 25S/68, adopted 18 October 1978.

111 The 1950 Report of the Working Party on 'The Use of Quantitative Restrictions for Protective and Commercial Purposes', GATT/CP.4/33, republished as "The Use of Quantitative Restrictions for Protective and Commercial Purposes," Sales No. GATT/1950-3, paras 21-23.
} 
Article XIII of GATT is not violated by either the quantitative restriction on certain products in the Catalogue or the upper monetary limits on a single transaction and the annual expenditure of a Chinese national. This is because the quantitative restriction and monetary limits could be used to purchase products from any source, meaning they satisfy Article XI:1, which states that 'the importation of the like product of all third countries... is similarly prohibited or restricted.' 112 This argument can find support from EEC-Import Regime for Bananas, in which the panel held that the EEC's tariff quota for imports of bananas did not discriminate between sources of supply in the Article XIII sense because the quota could be used for imports of bananas from any source. ${ }^{113}$

Nevertheless, the quantitative restriction and monetary limits are bottlenecks on the development of CERI. They aim to protect traditional retail businesses that compete with CERI. Fundamentally, they are imposed to protect the Chinese market. This is because CERI is China's attempt of unilateral trade liberalization, and Chinese products currently do not have the same favourable treatment from China's trading partners that China has offered to foreign products via CERI. China may gradually reduce the quantitative restriction and increase the upper monetary limits in order to meet Chinese consumers' growing demand for foreign products. However, the ultimate removal of these measures would depend on whether China's unilateral trade liberalization can create a snowball effect and bring bilateral or multilateral trade liberalization. ${ }^{114}$

\section{Market access}

In CERI, although consumers virtually shop around the world, they are physically in China. The services that foreign suppliers, cross-border e-commerce platforms, and payment companies provide may be categorized as 'Mode 1' (cross-border supply), meaning that they are provided from the territory of a foreign country into the territory of China. ${ }^{115}$ The fact that

\footnotetext{
${ }^{112}$ See Panel Report, EEC - Restrictions on Imports of Dessert Apples - Complaint by Chile, L/6491 - 36S/93, adopted 22 June 1989, paras 12.20-12.21 on the concept of 'all third countries'. See Panel Report, EEC Restrictions on Imports of Apples from Chile, L/5047 - 27S/98, adopted 10 November 1980, para 4.11 on the concept of 'similarly prohibited or restricted'.

${ }^{113}$ Panel Report, EEC-Import Regime for Bananas, DS38/R, dated 11 February 1994, paras 141-142.

${ }^{114}$ For discussion of the prospects of CERI, see below Section IV.C.

${ }^{115}$ Article 1:2(a) of GATS; WTO Appellate Body Report, United States-Measures Affecting the Cross-Border Supply of Gambling and Betting Services (US-Gambling), WT/DS285/AB/R, adopted 20 April 2005, paras 158-216 (considering that 'Mode 1' applies to gambling and betting services provided by suppliers located outside the US to consumers within the US); Panel Report, Mexico-Measures Affecting Telecommunications Services (Mexico-Telecoms), WT/DS204/R, adopted 1 June 2004, paras 7.25-7.45 (holding that the supply of a service through telecommunications from the US to Mexico is cross-border supply). For discussion of the difficulty in categorizing 'Mode 1' and 'Mode 2' service supplies, see Andrew D Mitchell, 'Towards
} 
Journal of International Economic Law, Volume 24, Issue 2, June 2021, Pages 299320, https://doi.org/10.1093/jiel/jgab018

these online services rely on the Internet network operated by Chinese companies in China does not change the legal nature of the services as cross-border supply. The Panel in MexicoTelecoms, for example, found that the relevant US companies provided cross-border supply into Mexico regardless of the fact that they linked their networks at the border with Mexican companies for termination within Mexico, 'without US's companies operating, or being present in some way, in Mexico'. 116

Regarding payment services, China has only made limited WTO and FTA commitments, including, for example, the transfer of financial information and the provision of other auxiliary financial services. ${ }^{117}$ Therefore, China can impose restrictions on foreign payment companies. The current restrictions include requiring payment companies to obtain business licenses at the Administration for Market Regulation in China. ${ }^{118}$ If payment companies are banking institutions, they must have a 'Financial License' issued by the China Banking and Insurance Regulatory Commission or the original China Banking Regulatory Commission. ${ }^{119}$ If payment companies are non-bank payment institutions, they must have a 'Payment Business License' issued by the People's Bank of China, and the scope of the payment business must include 'Internet Payment'. ${ }^{120}$

Importantly, in CERI, foreign suppliers are required to sell products through e-commerce platforms providers registered in China. ${ }^{121}$ Platforms are enterprises that operate information network systems to provide web storage, virtual business premises, transaction rules, information release and other services for consumers and foreign suppliers to conduct online e-commerce transactions. ${ }^{122}$ The platform is a third party independent from the foreign suppliers and consumers. The issue is whether the restriction (that foreign suppliers who want to conduct CERI must sell products via platforms registered in China) violates China's GATS commitments. The retail service that foreign suppliers provide belongs to the sector of

\footnotetext{
Compatibility: The Future of Electronic Commerce Within the Global Trading System', 4 Journal of International Economic Law 683 (2001), at 690-92. See also Jane Kelsey, 'How a TPP-Style E-Commerce Outcome in the WTO Would Endanger the Development Dimension of the GATS Acquis (and Potentially the WTO)', 21 Journal of International Economic Law 273 (2018), at 288-89.

${ }^{116}$ Panel Report, Mexico- Telecoms, above n 115, para 7.45.

${ }^{117}$ Page 31 of China's Specific Commitments under the WTO. For China's FTAs, see e.g. pg. 32 of China's Specific Commitments under the China-Australia FTA, signed on 17 June 2015 and effective on 20 December 2015. The China-Australia FTA is one of the most recent FTAs concluded by China so this paper uses it as an example.

${ }^{118}$ Customs Announcement No. 194 of 2018, above n 27, article 8.31.

${ }^{119}$ Circular No. 486 of 2018 , above n 7, article 3.1.

120 Ibid.

${ }^{121}$ Customs Announcement No. 194 of 2018, above n 27, articles 1.1 and 8.31; Circular No. 486 of 2018, above n 7 , articles 1 and 2 .

${ }^{122}$ Customs Announcement No. 194 of 2018, above n 27, articles 1.1 and 8.31; Circular No. 486 of 2018, above $\mathrm{n} 7$, articles 1 and 2 .
} 
Journal of International Economic Law, Volume 24, Issue 2, June 2021, Pages 299320, https://doi.org/10.1093/jiel/jgab018

'[w]holesale or retail trade services away from a fixed location' in China's Schedule of Specific Commitments on Services ('China's Specific Commitments') under its WTO Agreement and FTAs. ${ }^{123}$ China inscribed the word 'None' in the market access column for the mode of crossborder supply, meaning that it has committed to not introducing measures which in any way prohibit the means of delivery for cross-border supply. This includes supply through the Internet. ${ }^{124}$ Moreover, it may be argued that the retail service that foreign suppliers provide belongs to the sector of 'Retailing Services (excluding tobacco)' under China's Special Commitments. ${ }^{125}$ However, this argument is not persuasive as the CERI scheme does not allow any offline stores. ${ }^{126}$ It cannot be argued that foreign suppliers' warehouses in special customs supervision zones in Pilot Cities are 'fixed locations' for retail because such warehouses have no retail functions. Further, even if the warehouses are considered as fixed locations, such that the retail service that foreign suppliers provide in the Bonded Import falls into the sector of 'Retailing Services (excluding tobacco)', China indicates ' $[\mathrm{u}]$ nbound except for mail order' in the market access column for the mode of cross-border supply. ${ }^{127}$ This means that China promises not to restrict foreign retailers serving Chinese consumers by mail orders. Fundamentally, CERI has the same legal nature as mail orders because both concern tangible products which are sold and transported across border. The only difference is that, in the former, consumers use the Internet to place orders, while in the latter, consumers have to place orders by mail or telephone. China has thus undertaken treaty obligations not to impose market access restrictions on foreign suppliers in CERI. Therefore, foreign product suppliers should be allowed to use either their own websites or third-party platforms to sell products to Chinese consumers.

However, the services provided by the product suppliers' websites and third-party platforms involve not only retail services but also online information and/or data processing (including transaction processing) services, which constitute value-added telecommunications services. ${ }^{128}$ This is because e-commerce websites routinely provide data and transaction processing services for product suppliers and consumers. China imposes a commercial presence requirement for the mode of cross-border supply of value-added telecommunications

\footnotetext{
123 Page 23 of China's Specific Commitments under the WTO.

${ }^{124}$ See Panel Report, US-Gambling, WT/DS285/R, adopted 20 April 2005, para 6.287. For comments, see Sascha Wunsch-Vincent, 'The Internet, Cross Border Trade in Services, and the GATS: Lessons from US-Gambling', 5 World Trade Review 323 (2006), at 319-55.

125 Page 22 of China's Specific Commitments under the WTO.

${ }^{126}$ Circular No. 486 of 2018, above $\mathrm{n}$ 7, articles 4 and 5.2.

${ }^{127}$ Page 22 of China's Specific Commitments under the WTO.

${ }^{128}$ B21 of the Telecommunication Services Classification Catalogue (2015 Edition), published by China's Ministry of Industry and Information Technology on 1 March 2016 and amended on 6 June 2019.
} 
Journal of International Economic Law, Volume 24, Issue 2, June 2021, Pages 299320, https://doi.org/10.1093/jiel/jgab018

services. ${ }^{129}$ Foreign suppliers are only allowed to establish joint ventures in certain cities, and can only have up to $30 \%$ in shareholdings. ${ }^{130}$ Nevertheless, this geographic restriction has been removed and the foreign shareholding limit increased in subsequent FTAs. ${ }^{131}$ For example, the China-Australia FTA allows Australian service providers to establish joint ventures operating advanced telecommunication services in any place, with the foreign shareholding limit increased to $50 \% .{ }^{132}$ The foreign shareholding upper limit is further increased to $55 \%$ if the joint ventures are established in the Shanghai FTZs. ${ }^{133}$ In conclusion, product suppliers' websites or third-party platforms generally provide both retail services and value-added telecommunications services, with China imposing a commercial presence requirement for the latter. Thus, China's requirement that e-commerce platforms in CERI must be registered in China is not inconsistent with China's WTO Specific Commitments. There is an inconsistency, however, in China requiring foreign product suppliers to use platforms owned by a third party to conduct CERI; foreign suppliers should be allowed to use their own e-commerce websites.

The restriction that foreign suppliers must sell products through e-commerce platforms registered in China in order to conduct CERI may also violate Article III of GATT 1994. Although this restriction is imposed on the border, 'Brazil-Taxation' means that even premarket measures directed at producers that could affect internal sale or distribution by altering conditions of competition are covered by Article III. ${ }^{134}$ In Canada-Periodicals, the Appellate Body held that, fundamentally, Article III aims to ensure equality of competitive conditions between like imported and domestic products. ${ }^{135}$ Domestic Chinese suppliers can sell their products via their own websites without using third-party e-commerce platforms. Accordingly, foreign product suppliers should be allowed to do so.

In conclusion, CERI unilateralism does not bring liberalization in trade in services. This is because in addition to increasing consumer benefits, CERI was intended to develop Chinese ecommerce platforms and payment companies. Restricting market access for foreign platforms and payment companies results in foreign product suppliers having to sell on Chinese platforms.

\footnotetext{
129 Page 16 of China's Specific Commitments under the WTO.

${ }^{130}$ Ibid.

${ }^{131}$ E.g. pg. 18 of China's Specific Commitments under the China-Australia FTA.

132 Ibid.

133 Ibid.

${ }^{134}$ Paras 7.63-7.70 of Panel Report, Brazil-Certain Measures Concerning Taxation and Charges (BrazilTaxation), WT/DS472/R, WT/DS497/R, adopted 11 January 2019, confirmed by para 5.15 of WTO Appellate Body Report, Brazil-Certain Measures Concerning Taxation and Charges (Brazil-Taxation), WT/DS472/AB/R, WT/DS497/AB/R, adopted 11 January 2019.

135 Page 18 of WTO Appellate Body Report, Canada-Certain Measures Concerning Periodicals (CanadaPeriodicals), WT/DS31/AB/R, adopted 30 July 1997.
} 
Journal of International Economic Law, Volume 24, Issue 2, June 2021, Pages 299320, https://doi.org/10.1093/jiel/jgab018

Although China can require that platform providers must be registered in China, the restriction that foreign suppliers in CERI must conduct sales via third-party platforms is not consistent with China's Specific Commitments in GATS or Article III of GATT 1994.

\section{CONCLUSION AND PROSPECTS}

CERI represents a fifth generation of SEZ ${ }^{136}$ that reconceptualize and enhance consumer protection by treating consumers as diverse individuals rather than as a homothetic group. In CERI, although e-commerce platforms and payment companies must be registered in China, they may be (partially) owned by foreign investors, which has not yet led to investor-state disputes under FTAs or investment treaties. ${ }^{137}$ However, China should still ensure CERI fully complies with international trade and investment law.

The development of CERI warrants a rethinking of WTO multilateralism from its initial focus on corporations and capital owners to a revised focus on consumers. However, CERI unilateralism cannot fully replace WTO multilateralism or trade/investment regionalism. First, this is because CERI mainly covers consumable products, which inherently excludes many industrial products and raw materials. Second, the road to multilateral acceptance of both tariff exemptions and waivers relating to domestic quality and labelling regulations for consumable products would likely be long and rocky. At the international level, WTO law and most existing FTAs do not impose obligations on states to harmonize their consumer laws. When states have no treaty obligations, a strong domestic drive is required for states to offer unilateral trade liberalization. This drive exists in China but may not exist in other countries. This is because while CERI aligns with China's 2018 trade policy shift from being export-oriented to expanding imports and promoting a balanced development of international trade, ${ }^{138}$ not every other country has made, or would like to make, such a policy shift. Further, CERI allows China to develop its e-commerce industry and to shape global ecommerce laws, but countries without a strong domestic e-commerce industry may have little incentive to adopt CERI. Nevertheless, CERI fosters a consumer-oriented unilateralism that opens up a world of possibilities for future international trade law and policy.

\footnotetext{
136 \{insert a [CROSS-REFERENCE to James Nedumpara and Leila Choukroune article].

137 Julien Chaisse and Xueliang Ji, 'The Pervasive Problem of SEZs for International Economic Law: Tax, Investment, and Trade Issues', World Trade Rev (2020), at 1, at 12-17. Cross reference to Julien Chaisse, Dangerous Liaisons: The Story of Special Economic Zones, International Investment Agreements, and InvestorState Dispute Settlement.

${ }^{138}$ The Notice of Ministry of Commerce and other Departments on Expanding Imports and Promoting the Balanced Development of Foreign Trade, Forwarded by the General Office of the State Council, Guo Ban Fa [2018] No. 53 Hao, published by the State Council on 2 July 2018.
} 